\title{
Effects of new coated release fertilizer on the growth of maize
}

\author{
Y. J. Dong ${ }^{1}$, M.R. He ${ }^{2}$, Z.L. Wang' , W.F. Chen ${ }^{1}$, J. Hou ${ }^{1}$, X.K. Qiu ${ }^{1}$, J.W. Zhang ${ }^{2 *}$ \\ ${ }^{1}$ College of Resources and Environment, Shandong Agricultural University, Tai'an, 271018, Shandong \\ Province, China. \\ ${ }^{2}$ College of Agronomic Sciences, Shandong Agricultural University, Tai'an 271018, Shandong Province, Chi- \\ na. Corresponding author: jwzhang@sdau.edu.cn
}

\begin{abstract}
Slow or controlled release fertilizers have been researched and used more and more widely, developing new slow or controlled release fertilizers is very important. To improve the use efficiency of inorganic fertilizers through the use of coated fertilizer and nitrification inhibitors, 3 newly developed fertilizers (FCRF1:coated fertilizer $+1 \%$ DCD, FCRF2: coated fertilizer $+2 \%$ DCD and FCRF3:coated fertilizer + 4\% DCD) amended with nitrification inhibitors $\left(\mathrm{DCD}, \mathrm{C}_{2} \mathrm{H}_{4} \mathrm{~N}_{4}\right.$ ), and coated with fly ash were prepared by coating conventional compound fertilizer (N-P-K: 15-6.55-12.4). Using a coated fertilizer (resin coated compound fertilizer, N-P-K: 15-6.55-12.4, 90 day, CRF) made in China and a conventional compound fertilizer (CCF) as checks, their effects on physiological characteristics, yield and quality of maize were examined in a field experiment. The results indicated that, compared to CCF, 3 new developed fertilizers kept higher ammonium nitrogen $\left(\mathrm{NH}_{4}{ }^{+} \mathrm{N}\right)$ and nitrate nitrogen $\left(\mathrm{NO}_{3}^{-}-\mathrm{N}\right)$ content at later stages and FCRF3 had the highest content, being similar to CRF treatment. At tasselling stage (TS) and filling stage (FS), the chlorophyll content, photosynthetic rate, transpiration rate and chlorophyll fluorescence parameters were significantly increased upon FCRF1, FCRF2 and FCRF3 treatments. In addition, FCRF1, FCRF2 and FCRF3 treatments produced 24.0-35.8\% more grain yield, 57.2\%$74.4 \%$ more total yield, increased $11.20 \%-49.55 \%$ starch, $61.38 \%-113 \%$ protein and $2.67 \%-9.33 \%$ Vitamine C content than CCF, respectively. This product with excellent slow release capacity, being easy to get at a low price and environment-friendly, could be especially useful in agricultural application.
\end{abstract}

Keywords: Coated fertilizer, nitrification inhibitor, fly ash, physiological characteristics, maize

\section{Introduction}

Slow or controlled release fertilizers have been researched and used more and more widely, which can effectively reduce nutrition loss and one important type of them is coated fertilizer. Coated fertilizers are physically prepared by coating granules of conventional fertilizers with various materials that re- 
duce their dissolution rate. The release and dissolution rates of water-soluble fertilizers depend on the coating materials (Wu et al. 2008). As the price of organic polymer coated fertilizer was too high, some inorganic materials and aldehydes were used to make new fertilizer. Paraformal-dehyde was also used to coat compound fertilizer, and the release amount of nutrient $(\mathrm{N}, \mathrm{P}$ and $\mathrm{K})$ in water and soil is lower than $75 \%$ on the 30 th day compared to uncoated fertilizer, being environmentally friendly (Zhao et al. 2010). Other new controlled or slowed fertilizers were reported, containing such coated materials as polymer (Du et al. 2006), fly ash (Qiu et al. 2011) and superfine phosphorus rock powder (SPRP) (Hou et al. 2014).

Improvement in fertilizer use efficiency of inorganic fertilizers through the use of $\mathrm{N}$ inhibitors may play a key role in increasing productivity as well as minimizing environmental damage (Chen et al. 2008). Nitrification inhibitor is not a new technology, and one of the most widely used inhibitor, dicyandiamide (DCD, $\mathrm{C}_{2} \mathrm{H}_{4} \mathrm{~N}_{4}$ ), was shown to affect plant growth in the 1920s (McGuinn 1924). Many studies have shown that DCD can significantly decrease $\mathrm{NO}_{3}^{-}$leaching and $\mathrm{N}_{2} \mathrm{O}$ emissions from cropping systems or grazed pasture systems (Di et al. 2007; Jumadi et al. 2008; Cui et al. 2011), which is a common nitrification inhibitor that is naturally broken down in the soil, with no traces of residue left beyond the cropping year (Singh and Verma, 2007). DCD inhibits the first stage of nitrification, the oxidation of $\mathrm{NH}_{4}^{+}$to $\mathrm{NO}_{2}^{-}$, by rendering the bacteria's enzyme ineffective (Di and Cameron, 2003). Temperature is the factor having the most influences on the effectiveness of DCD; an increase in temperature can have a negative effect on the persistence of DCD in the soil, reducing the time frame in which it can be effective at reducing nitrification (Kelliher et al., 2008). Selbie et al. (2011) reported that
DCD reduced $\mathrm{NO}_{3}^{-}$leaching by $45 \%$ and $\mathrm{N}_{2} \mathrm{O}$ emissions by $70 \%$ on dairy cow urine treatments on Irish soils. Richards et al. (2008) also reported that DCD application on urine patches reduced $\mathrm{NO}_{3}^{-}$leaching, especially on Irish soils. Zaman and Blennerhassett (2010) reported that the application of DCD to spring deposited urine increased herbage production by an average of $12 \%$.

However, the prices of slow release or controlled release fertilizers are much higher than that of normal fertilizer, which is hard to be accepted by farmers (Yan et al. 2008), and the coated fertilizer had other disadvantage such as complex making process, long degradation time and polluting the environment (Sartain et al. 2003). Fly ash as inorganic material was used to coat compound fertilizer, but the homemade fertilizer still never had more perfect effect than resin coated one (Qiu et al. 2011).

Moreover, coated fertilizers especially with inorganic material as coated material amended nitrification inhibitor to increase crop growth have been reported rarely. This paper studied physiological characteristics, yield and quality of maize under fly ash coated fertilizer amended with different added amount of DCD. The objective of this study was to find an effective coated fertilizer amending with appropriate DCD addition for improving maize growth and explore new style of nitrification inhibitor application.

\section{Materials and Methods}

\subsection{Preparation of new developed fertilizer}

Common compound fertilizer was used as core material, and the main coated material was fly ash. The common fertilizer was coated with fly ash, polyving akohol (one kind of organic binder bond) and so on, 
which were all passed through a $0.1 \mathrm{~mm}$ sieve and determined for water release trial. The newly developed fertilizer was made by disk granulation. A disk granulator mainly included a disk with a diameter of 80 $\mathrm{cm}$, a power motor of $0.55 \mathrm{~kW}$, a governor, and stand composition (Figure 1). Coated materials accounted for $25 \%$ of the total mass, and fly ash (The fly ash took from thermal power plant of Tai' an city of Shandong province. Some physical properties of the fly ash, as follow: Bulk density $\left(0.82 \mathrm{~g} \cdot \mathrm{cm}^{-3}\right)$; Density $(1.84$ $\left.\mathrm{g} \cdot \mathrm{cm}^{-3}\right)$; Water content $(0.17 \%)$; Panicle composition (1.00 0.05 mm: $245.86 \mathrm{~g} \cdot \mathrm{kg}^{-1} ; 0.05 \sim 0.01 \mathrm{~mm}: 468.84$ $\mathrm{g} \cdot \mathrm{kg}^{-1} ; 0.01 \sim 0.005 \mathrm{~mm}: 220.36 \mathrm{~g} \cdot \mathrm{kg}^{-1} ; 0.005 \sim 0.001$ $\left.\mathrm{mm}: 42.10 \mathrm{~g} \cdot \mathrm{kg}^{-1} ;<0.001 \mathrm{~mm}: 22.84 \mathrm{~g} \cdot \mathrm{kg}^{-1}\right)$. Some chemical properties of the fly ash, as follow: Total
$\mathrm{N}\left(0.09 \mathrm{~g} \cdot \mathrm{kg}^{-1}\right)$; Available N (15.30 $\left.\mathrm{mg} \cdot \mathrm{kg}^{-1}\right)$; Total P (1.90 g. $\left.\mathrm{kg}^{-1}\right)$; Available P $\left(94.85 \mathrm{mg} \cdot \mathrm{kg}^{-1}\right)$; Total K (1.61 $\left.\mathrm{g} \cdot \mathrm{kg}^{-1}\right)$; Available K (173 $\left.\mathrm{mg} \cdot \mathrm{kg}^{-1}\right)$; Fe (2635 $\left.\mathrm{mg} \cdot \mathrm{kg}^{-1}\right) ; \mathrm{Zn}\left(23 \mathrm{mg} \cdot \mathrm{kg}^{-1}\right) ; \mathrm{Cu}\left(16 \mathrm{mg} \cdot \mathrm{kg}^{-1}\right) ; \mathrm{Cd}(5.6$ $\left.\mathrm{mg} \cdot \mathrm{kg}^{-1}\right) ; \mathrm{Pb}\left(46 \mathrm{mg} \cdot \mathrm{kg}^{-1}\right)$ was added by $15 \%$ of the total mass. The adding rate of DCD was $1 \%, 2 \%$ and $4 \%$ of total coated fertilizer (w/w), respectively (Xu et al. 2002; Zhao et al. 1993). The newly developed fertilizer contained $24 \%$ coated materials $+75 \%$ conventional compound fertilizer (N-P-K: 15-6.55-12.40) +1\% dicyandiamide (FCRF1), 23\% coated materials $+75 \%$ conventional compound fertilizer (N-P-K: 15-6.55-12.40) $+2 \%$ dicyandiamide (FCRF2) and $21 \%$ coated materials $+75 \%$ conventional compound fertilizer (N-P-K: $15-6.55-12.40)+4 \%$ dicyandiamide (FCRF3).

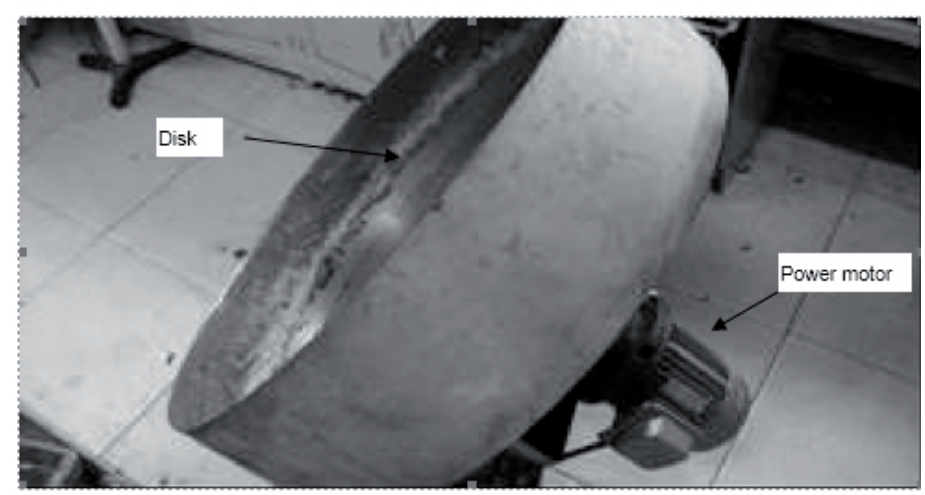

Figure 1. Disk granulator used to make the newly developed fertilizer. 


\subsection{Plant and fertilizer material and growth conditions}

A field experiment was conducted on alfisol (named in The USDA-NRCS soil taxonomy nomenclature) during the growing season of maize in 2011 at College of Resources and Environment, Shandong Agricultural University, China. The topsoil $(0-20 \mathrm{~cm})$ had an EC of $197.1 \mu \mathrm{S} \mathrm{cm}^{-1}$ (soil water ratio 1:5), and contained $14.1 \mathrm{~g} \mathrm{~kg}^{-1}$ organic matter, $0.622 \mathrm{~g} \mathrm{~kg}^{-1}$ total nitrogen, $46.5 \mathrm{mg} \mathrm{kg}^{-1}$ available nitrogen, $22.5 \mathrm{mg} \mathrm{kg}^{-1}$ available phosphorus, $106.1 \mathrm{mg} \mathrm{kg}^{-1}$ available potassium. Maize (Zea mays) (Wuyue 206) was used.

Treatments consisted of 6 treatments: CK (a control without fertilizer), CCF (common compound fertilizer, N-P-K: 15-6.55-12.40), CRF (resin coated compound fertilizer, N-P-K: 15-6.55-12.40, 90 day,), FCRF1, FCRF2 and FCRF3. All fertilization treatments received the same amount of $\mathrm{N}\left(150 \mathrm{~kg} \mathrm{ha}^{-1}\right)$, $\mathrm{P}\left(65.50 \mathrm{~kg} \mathrm{ha}^{-1}\right)$ and $\mathrm{K}\left(123.97 \mathrm{~kg} \mathrm{ha}^{-1}\right)$ at sowing. All fertilization treatments were applied with maize sowing once. The experiment was conducted in a 12 $\mathrm{m}^{2}$ plot $(10 \mathrm{~m} \times 1.2 \mathrm{~m})$ with completely randomized block design and 3 replications. Each plot had two rows $40 \mathrm{~cm}$ apart and each plant was $30 \mathrm{~cm}$ apart. There was a $20 \mathrm{~cm}$ wide ditch between the plots. Maize was sown on April 28, 2 granules per hole and each plot kept 1 better seeding. Plants were harvested on August 20. The measures of pest control and other management were same with the local field.

\section{3. $\mathrm{NH}_{4}^{+}-\mathrm{N}$ and $\mathrm{NO}_{3}^{-}-\mathrm{N}$ content measurement}

A $50 \mathrm{~mm}$ diameter auger was used to collect the soil sample. At the maize stages of tasselling stage (TS), filling stage (FS) and maturity stage (MS), three composite soil samples were collected from all plots at depths of 0 to $20 \mathrm{~cm}$. Three replicates of $10 \mathrm{~g}$ (fresh weight) portions of soils were extracted with $50 \mathrm{~mL} 2$ $\mathrm{mol} / \mathrm{L} \mathrm{KCl}$ for 30 min to determine the concentrations of mineral $\mathrm{N}$ (including $\mathrm{NO}_{3}^{-}$and $\mathrm{NH}_{4}^{+}$) using a continuous-flow analyzer (Soil Science Society of China 1999, NADA, 2015).

2.4. SPAD index (chlorophyll relative content), net photosynthetic rate $(P n)$, transpiration rate $(\mathrm{Tr})$ measurement and determination of chlorophyll fluorescence

Three to five plants per plot were measured. A portable chlorophyll meter (SPAD502) was used to determine SPAD index throughout the growing season such as joining stage (JS), tasselling stage (TS), filling stage (FS) and maturity stage (MS), leaves in the upper part of the plants.

By using photosynthesis system (CIRAS-2, UK), the young leaves were selected to measure Pn and Tr between 9:00-10:00 AM at 4 stages. Chlorophyll fluorescence was measured with a pulse amplitude modulated system (model FMS2, Hanseatic Instruments, UK) according to Burzyriski and Klobus (2004).

\subsection{Agronomic characters and plant yield measure-} ment

At the physiological mature stage of maize, two adjacent rows in the middle of each replication were harvested (area $=5 \mathrm{~m} \times 1.2 \mathrm{~m}$ ). Five plants were selected at random in the harvested plants, and then divided into grains and stover (including stalk, leaves, husks and cob), and weighed separately.

The organ samples were put into oven to deactivate enzymes at $105^{\circ} \mathrm{C}$ for $30 \mathrm{~min}$, and then oven-dried at $80{ }^{\circ} \mathrm{C}$ for $72 \mathrm{~h}$ to determine dry matter yield.

After that, the agronomic characters (Rows per ear, Kernels per row, Ear length, Kernels per ear, 1000-kernel weight, Bulk density) of maize were measured separately. 
2.6. Protein, oluble ugar, tarch, and vitamine $C$ contents assay

Soluble sugar and Vitamine $\mathrm{C}$ in the maize were all analyzed in fresh plant samples. Grain protein concentration was calculated as $\mathrm{N}$ contents $\times 5.7$. Watersoluble sugars were determined using the gravimetric Fehling's method, anthrone colorimetry method was adopted to measure the contents of starch, and VC was extracted with $0.22 \mathrm{M}$ oxalic acid and analyzed by the 2,6-dichlorophenolindophenol sodium salt titrimetric method (Williams., 1984, Milošević. 2015).

\subsection{Data analysis}

The Tukey's test was used to test the effect of different treatments, and the least significant difference (LSD) was calculated to compare the differences between means in each treatment, correlative analysis using the SPSS software (SPSS 11.5).

\section{Results}

3.1. $\mathrm{NH}_{4}^{+}-\mathrm{N}$ and $\mathrm{NO}_{3}^{-}-\mathrm{N}$ contents

As shown in Figure 2, compared to control, the other fertilization treatments variously increased $\mathrm{NH}_{4}^{+}$$\mathrm{N}$ and $\mathrm{NO}_{3}^{-}-\mathrm{N}$ content. At TS, the $\mathrm{NH}_{4}^{+}-\mathrm{N}$ content of CRF was largest, whereas after that the $\mathrm{NH}_{4}{ }^{+} \mathrm{N}$ content increased significantly in all treatments, especially at FS, the content of all coated fertilizer were in trend of FCRF3 $>$ FCRF2 $>$ CRF $>$ FCRF1. At MS, the $\mathrm{NO}_{3}^{-}-\mathrm{N}$ content of all treatments were largest, while at FS, the critical stage, the content of all coated fertilizer treatments were in trend of FCRF $3>$ CRF $>$ FCRF2 $>$ FCRF 1 .

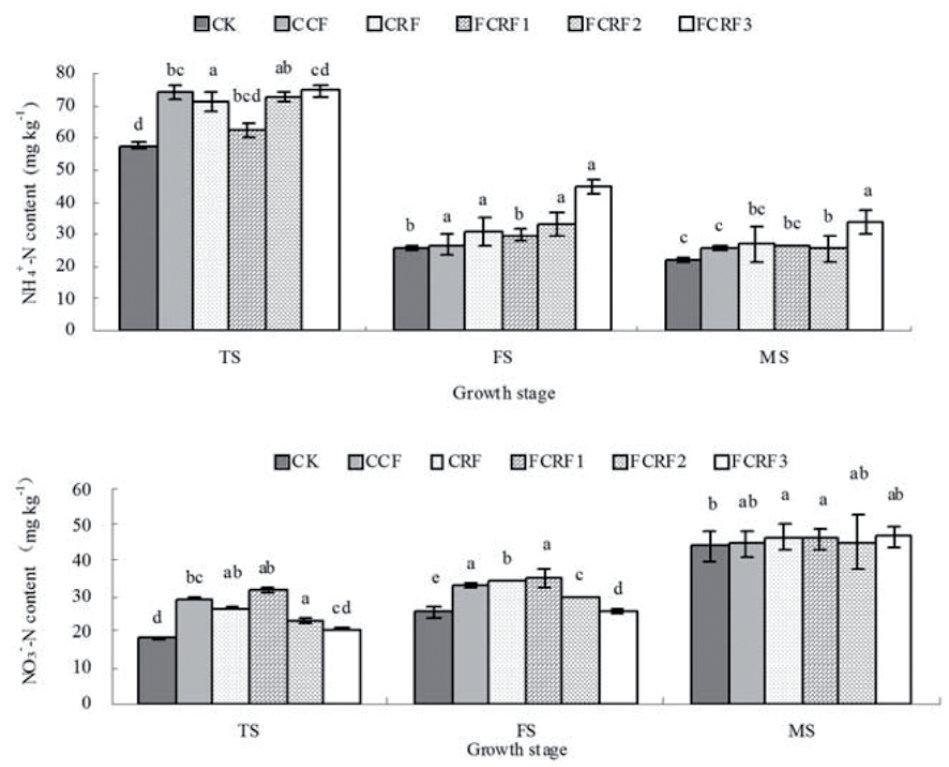

Figure 2. Effects of different fertilization treatments on $\mathrm{NH}_{4}^{+}-\mathrm{N}$ and $\mathrm{NO}_{3}^{-}-\mathrm{N}$ contents of soil. The Tukey's test was used to test the effect of different treatments, and the least significant difference (LSD) was calculated to compare the differences between means in each treatment. Values are the means $\pm \mathrm{SD}$ of three replicates. The values followed by the different letter show statistically significant differences at $\mathrm{P}<0.05$. 


\subsection{SPAD index}

Fertilizer type affected SPAD index differently at the sampling times (Table 1). Compared to CK, the other fertilization treatments increased the SPAD index of maize by a certain extent. At MS, FCRF1, FCRF2 and FCRF3 treatments had 29.38\%, 27.73\%, 27.49\% higher content compared to CCF, even higher than CRF.

Table 1. Effects of different fertilizer treatments on SPAD index of maize leaves

\begin{tabular}{ccccc}
\hline Treatments & Joining stage & Tasselling stage & Filling stage & Maturity stage \\
\hline CK & $41.9 \pm 2.3 \mathrm{c}$ & $46.0 \pm 0.3 \mathrm{c}$ & $44.4 \pm 2.2 \mathrm{~d}$ & $36.0 \pm 2.8 \mathrm{~d}$ \\
CCF & $48.1 \pm 1.8 \mathrm{ab}$ & $49.1 \pm 1.8 \mathrm{bc}$ & $51.7 \pm 3.0 \mathrm{c}$ & $42.2 \pm 1.6 \mathrm{c}$ \\
CRF & $47.8 \pm 1.8 \mathrm{ab}$ & $52.9 \pm 3.8 \mathrm{ab}$ & $55.7 \pm 0.2 \mathrm{ab}$ & $46.2 \pm 1.0 \mathrm{~b}$ \\
FCRF1 & $49.7 \pm 1.3 \mathrm{a}$ & $53.1 \pm 3.0 \mathrm{ab}$ & $58.8 \pm 1.5 \mathrm{a}$ & $54.6 \pm 1.6 \mathrm{a}$ \\
FCRF2 & $45.2 \pm 0.4 \mathrm{bc}$ & $52.0 \pm 2.3 \mathrm{ab}$ & $58.4 \pm 1.9 \mathrm{a}$ & $53.9 \pm 2.5 \mathrm{a}$ \\
FCRF3 & $46.6 \pm 4.7 \mathrm{ab}$ & $54.6 \pm 3.0 \mathrm{a}$ & $54.4 \pm 0.7 \mathrm{bc}$ & $53.8 \pm 1.7 \mathrm{a}$ \\
\hline
\end{tabular}

Notes: The Tukey's test was used to test the effect of different treatments, and the least significant difference (LSD) was calculated to compare the differences between means in each treatment.Values are the means \pm SD of three replicates. The values followed by the different letter show statistically significant differences at $\mathrm{P}<0.05$.
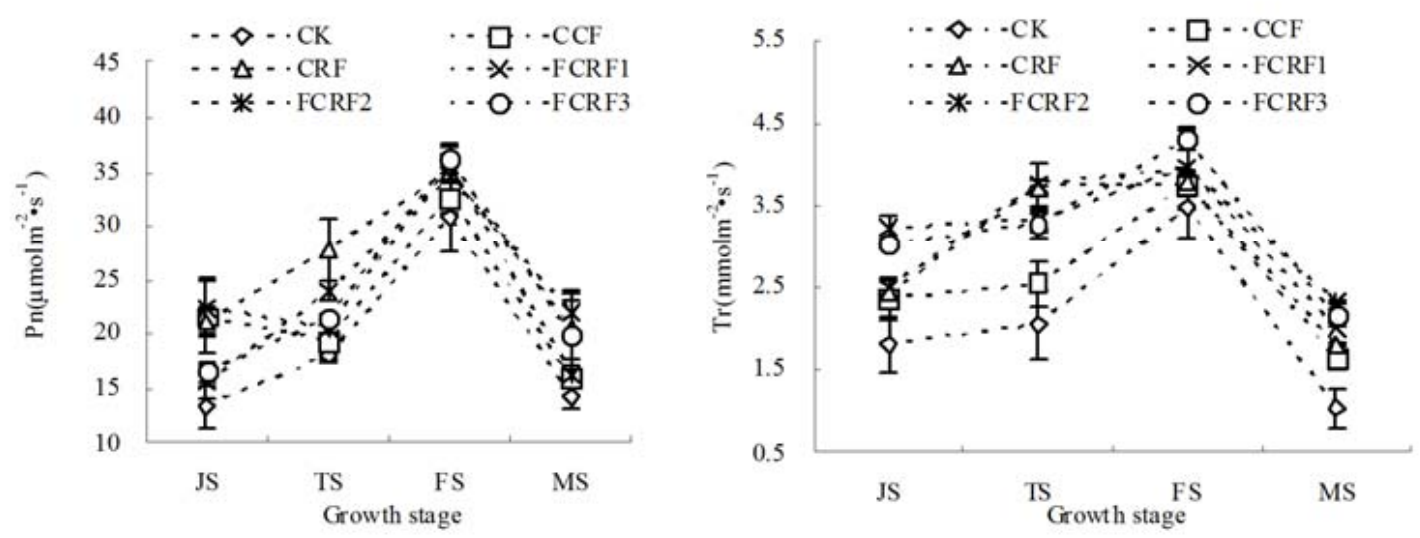

Figure 3. Effects of different fertilization treatments on net photosynthetic rate and transpiration rate of maize leaves. The Tukey's test was used to test the effect of different treatments, and the least significant difference (LSD) was calculated to compare the differences between means in each treatment. Values are the means $\pm \mathrm{SD}$ of three replicates. The values followed by the different letter show statistically significant differences at $\mathrm{P}<0.05$. 
Table 2. Effects of different fertilizer treatments on chlorophyll fluorescence parameters of maize leaves (Filling stage)

\begin{tabular}{ccccccc}
\hline Treatments & Fo & Fm & Fv/ Fm & $\Phi P s l l$ & qP & NPQ \\
\hline CK & $52.5 \pm 0.5 \mathrm{c}$ & $258.5 \pm 1.5 \mathrm{e}$ & $0.79 \pm 0.01 \mathrm{~b}$ & $0.57 \pm 0.08 \mathrm{~b}$ & $0.69 \pm 0.12 \mathrm{c}$ & $0.71 \pm 0.16 \mathrm{a}$ \\
CCF & $56.0 \pm 4.0 \mathrm{bc}$ & $288.0 \pm 8.0 \mathrm{~d}$ & $0.80 \pm 0.01 \mathrm{ab}$ & $0.62 \pm 0.06 \mathrm{ab}$ & $0.89 \pm 0.05 \mathrm{ab}$ & $0.51 \pm 0.08 \mathrm{~b}$ \\
CRF & $56.0 \pm 1.0 \mathrm{bc}$ & $304 \mid 5 \pm 8.5 \mathrm{c}$ & $0.82 \pm 0.00 \mathrm{a}$ & $0.67 \pm 0.04 \mathrm{a}$ & $0.83 \pm 0.08 \mathrm{bc}$ & $0.26 \pm 0.01 \mathrm{c}$ \\
FCRF1 & $77.5 \pm 1.5 \mathrm{a}$ & $326.5 \pm 6.5 \mathrm{~b}$ & $0.81 \pm 0.01 \mathrm{ab}$ & $0.63 \pm 0.01 \mathrm{ab}$ & $1.01 \pm 0.14 \mathrm{a}$ & $0.53 \pm 0.06 \mathrm{~b}$ \\
FCRF2 & $55.5 \pm 3.5 \mathrm{c}$ & $307.5 \pm 3.5 \mathrm{c}$ & $0.81 \pm 0.01 \mathrm{ab}$ & $0.61 \pm 0.00 \mathrm{ab}$ & $0.84 \pm 0.00 \mathrm{~b}$ & $0.51 \pm 0.05 \mathrm{~b}$ \\
FCRF3 & $61.0 \pm 4.0 \mathrm{~b}$ & $348.5 \pm 3.5 \mathrm{a}$ & $0.82 \pm 0.01 \mathrm{a}$ & $0.69 \pm 0.02 \mathrm{a}$ & $0.89 \pm 0.02 \mathrm{ab}$ & $0.28 \pm 0.00 \mathrm{c}$ \\
\hline
\end{tabular}

Notes: The Tukey's test was used to test the effect of different treatments, and the least significant difference (LSD) was calculated to compare the differences between means in each treatment. Values are the means \pm SD of three replicates. The values followed by the different letter show statistically significant differences at $\mathrm{P}<0.05$.

\subsection{Net photosynthetic rate $(P n)$ and transpiration rate (Tr)}

There were significant differences in $\mathrm{Pn}$ and $\mathrm{Tr}$ in maize leaves in different treatments (Figure 3). From Fs to MS, Pn was decreased by a certain extent and was similar to the change of chlorophyll content (Table 1). This was due to chlorophyll was a limitation factor which affected photosynthesis, and had a good correlation with photosynthetic performance. The CCF treatment showed the highest at Js stage, but it became the lowest at the other three stages. Compared to CCF, Pn decreased slowly in the other coated fertilizer treatments, especially at later stages. At FS, FCRF1, FCRF2 and FCRF3 treatments promoted net Pn by $5.98 \%, 9.14 \%$ and $11.33 \%$ than treatment with $\mathrm{CCF}$, and there were no significant difference between all these coated fertilizers; at MS, FCRF1, FCRF2 and FCRF3 increased Pn by $38.40 \%, 2.36 \%$ and $25.13 \%$ than CCF. This revealed under coalition of coated materials and nitrification inhibitor, homemade fertilizers made the nutrient gradually release to soil, and it furthermore affected Pn.
AS shown in Figure 3, fertilization increased Tr significantly, and the value of all treatments increased firstly and decreased later, the Tr was largest at FS, being similar to chlorophyll content and Pn (Table 1, Figure 3).

CCF increased Tr at TS, however, FCRF1, FCRF2 and FCRF3 increase $\mathrm{Tr}$ at later stages. They improved it by $5.03 \%, 5.42 \%$ and $14.02 \%$ at FS and $22.12 \%, 40.61 \%$ and $30.61 \%$ at MS compared to CCF.

\subsection{Chlorophyll fluorescence parameters}

Growth-dependent variations in the maximum quantum yield of PS II photochemistry (Fv/Fm), actual efficiency of photochemical energy conservation in PS II under steady-steady (light) conditions ( ФPS II ), photochemical quenching coefficient Qp in response to different fertilizer treatments for leaves of maize were presented in Table 2.

Fertilization increased Fo and Fm value. FCRF1, FCRF2 and FCRF3 had higher Fo value than CCF, which increased by $13.37 \%, 6.77 \%$ and $21.01 \%$. 
Moreover, they increased Fv/Fm, ФPS II and Qp respectively, but decreased NPQ (Table 2).

\subsection{Effects of different fertilizer treatments on agronomic characters}

Fertilization significantly increased kernels per row and kernels per ear than CK (Table 3). Moreover,
FCRF1, FCRF2 and FCRF3 had higher kernels per row and kernels per ear than CCF and CRF, and FCRF2 significantly increased kernels per ear than CCF. The weight per 1000-kemel of maize were in a trend of $\mathrm{FCRF} 1>\mathrm{FCRF} 2>\mathrm{FCRF} 3>\mathrm{CRF}>\mathrm{CCF}>\mathrm{CK}$. Furthermore, fertilization increased bulk of maize significantly, especially in CRF, FCRF1 and FCRF2 treatments.

Table 3. Effects of different fertilizer treatments on agronomic characters of maize

\begin{tabular}{|c|c|c|c|c|c|c|}
\hline Treatments & $\begin{array}{c}\text { Rows per ear } \\
\text { (No./Plant) }\end{array}$ & $\begin{array}{l}\text { Kernels per row } \\
\text { (No./Plant) }\end{array}$ & $\begin{array}{l}\text { Ear length } \\
\text { (No./Plant) }\end{array}$ & $\begin{array}{l}\text { Kernels per ear } \\
\text { (No./Plant) }\end{array}$ & $\begin{array}{c}\text { 1000-kernel weight } \\
(\mathrm{g})\end{array}$ & $\begin{array}{l}\text { Bulk } \\
\text { density } \\
\left(\mathrm{g} \mathrm{L}^{-1}\right)\end{array}$ \\
\hline CK & $13.0 \pm 1.3 \mathrm{~b}$ & $20.3 \pm 4.2 \mathrm{c}$ & $15.2 \pm 2.6 \mathrm{~d}$ & $264.5 \mathrm{~d}$ & $251.0 \mathrm{c}$ & $614.2 \mathrm{~b}$ \\
\hline $\mathrm{CCF}$ & $14.2 \pm 0.4 \mathrm{ab}$ & $27.2 \pm 2.5 b$ & $17.7 \pm 0.9 \mathrm{~cd}$ & $387.0 \mathrm{c}$ & $276.9 \mathrm{bc}$ & $650.2 \mathrm{~b}$ \\
\hline CRF & $15.4 \pm 1.2 \mathrm{a}$ & $31.3 \pm 1.3 b$ & $20.2 \pm 0.3 \mathrm{bc}$ & $480.1 \mathrm{bc}$ & $284.4 \mathrm{abc}$ & $700.1 \mathrm{a}$ \\
\hline FCRF1 & $15.3 \pm 0.7 \mathrm{a}$ & $39.1 \pm 4.0 \mathrm{a}$ & $22.5 \pm 2.5 \mathrm{ab}$ & $601.3 \mathrm{a}$ & $335.1 \mathrm{a}$ & $714.0 \mathrm{a}$ \\
\hline FCRF2 & $14.7 \pm 1.5 \mathrm{ab}$ & $39.4 \pm 4.1 \mathrm{a}$ & $23.2 \pm 1.0 \mathrm{a}$ & $576.4 \mathrm{ab}$ & $325.7 \mathrm{ab}$ & $715.9 \mathrm{a}$ \\
\hline FCRF3 & $13.9 \pm 1.5 \mathrm{ab}$ & $38.5 \pm 1.4 \mathrm{a}$ & $22.4 \pm 0.4 \mathrm{ab}$ & $536.1 \mathrm{ab}$ & $311.9 \mathrm{ab}$ & $660.7 \mathrm{ab}$ \\
\hline
\end{tabular}

Notes: The Tukey's test was used to test the effect of different treatments, and the least significant difference (LSD) was calculated to compare the differences between means in each treatment. Values are the means $\pm \mathrm{SD}$ of three replicates. The values followed by the different letter show statistically significant differences at $\mathrm{P}<0.05$.

\subsection{Effects of different fertilizer treatments on yield}

Coated fertilizers improved pod yield and total yield significantly (Table 4). The pod yield of maize were in trend of $\mathrm{FCRF} 3>\mathrm{CRF}>\mathrm{FCRF} 2>\mathrm{FCRF} 1>\mathrm{CCF}>\mathrm{CK}$, and fertilization significantly increased grain yield by $21.9 \%-65.5 \%$ than CK, FCRF 1, FCRF 2 and FCRF3 increased grain yield by $24.0 \%, 31.4 \%$ and $35.8 \%$ than $\mathrm{CCF}$.

Compared to CCF, FCRF1, FCRF2 and FCRF3 improved total yield by $57.2 \%, 64.6 \%$ and $74.4 \%$ , especially FCRF3 showed more obvious effect than CRF.

\subsection{Effects of different fertilizer treatments on quality}

Compared to $\mathrm{CK}$, fertilization can improve starch, fat, protein, soluble sugar, and vitamin $\mathrm{C}$ (Table 5). Fertilization increased starch in grain by $18.12 \% \sim 76.65 \%$, FCRF2 and FCRF3 had more obvious effect on starch, fat and protein content.

Though fertilization increased soluble sugar content, it showed no significant difference in different treatments. While fertilization increased vitamin $\mathrm{C}$ by $3.45 \%-15.86 \%$, especially FCRF 1, FCRF 2 and FCRF 3 increased it by $6.00 \%, 2.67 \%$ and $9.33 \%$ than $\mathrm{CCF}$ (Table 5). In a word, FCRF1 did the best effect on fat, while FCRF2 and FCRF3 had more beneficial effect on other quality of maize. 
Table 4. Effect of different fertilizer treatments on yields of maize

\begin{tabular}{|c|c|c|c|c|c|c|}
\hline \multirow[t]{2}{*}{ Treatments } & \multicolumn{3}{|c|}{ Grain yield $\left(\mathrm{kg} \mathrm{hm}^{-2}\right)$} & \multicolumn{3}{|c|}{ Total yield $\left(\mathrm{kg} \mathrm{hm}^{-2}\right)$} \\
\hline & $\begin{array}{c}\text { Yield } \\
\left(\mathrm{kg} / \mathrm{hm}^{2}\right)\end{array}$ & Compare to $\mathrm{CK}( \pm \%)$ & Compare to CCF $( \pm \%)$ & $\begin{array}{c}\text { Yield } \\
\left(\mathrm{kg} / \mathrm{hm}^{2}\right)\end{array}$ & Compare to $\mathrm{CK}( \pm \%)$ & Compare to $\mathrm{CCF}( \pm \%)$ \\
\hline $\mathrm{CK}$ & $4685.0 \mathrm{~d}$ & - & - & $16658.3 \mathrm{e}$ & - & - \\
\hline $\mathrm{CCF}$ & $5710.5 \mathrm{c}$ & 21.9 & - & $33354.2 \mathrm{~d}$ & 18.3 & - \\
\hline CRF & $7621.7 \mathrm{ab}$ & 62.7 & 33.5 & $50725.4 \mathrm{c}$ & 38.4 & 17.0 \\
\hline FCRF1 & $7078.6 \mathrm{~b}$ & 51.1 & 24.0 & $68171.6 \mathrm{~b}$ & 86.0 & 57.2 \\
\hline FCRF2 & $7504.8 \mathrm{ab}$ & 60.2 & 31.4 & $71379.4 b$ & 94.7 & 64.6 \\
\hline FCRF3 & $7753.9 \mathrm{a}$ & 65.5 & 35.8 & 83938.6a & 106.2 & 74.4 \\
\hline
\end{tabular}

Notes: The Tukey's test was used to test the effect of different treatments, and the least significant difference (LSD) was calculated to compare the differences between means in each treatment. Values are the means $\pm \mathrm{SD}$ of three replicates. The values followed by the different letter show statistically significant differences at $\mathrm{P}<0.05$.

Table 5. Effects of different fertilizer treatments on quality of maize

\begin{tabular}{cccccc}
\hline Treatments & $\begin{array}{c}\text { Starch } \\
(\%)\end{array}$ & $\begin{array}{c}\text { Fat } \\
(\%)\end{array}$ & $\begin{array}{c}\text { Protein } \\
(\%)\end{array}$ & $\begin{array}{c}\text { Soluble sugar } \\
\left(\mathrm{mg} \mathrm{g}^{-1}\right)\end{array}$ & $\begin{array}{c}\text { Vitamine C } \\
\left(\mathrm{mg} \mathrm{kg}^{-1}\right)\end{array}$ \\
\hline CK & $17.99 \pm 3.14 \mathrm{~d}$ & $9.35 \pm 0.51 \mathrm{~d}$ & $1.74 \pm 0.58 \mathrm{c}$ & $70.23 \pm 1.85 \mathrm{c}$ & $14.50 \pm 0.50 \mathrm{c}$ \\
CCF & $21.25 \pm 0.65 \mathrm{~cd}$ & $9.64 \pm 0.39 \mathrm{bcd}$ & $2.46 \pm 0.44 \mathrm{c}$ & $77.65 \pm 4.17 \mathrm{ab}$ & $15.00 \pm 0.60 \mathrm{bc}$ \\
CRF & $24.70 \pm 2.51 \mathrm{~b}$ & $9.91 \pm 0.13 \mathrm{abc}$ & $4.33 \pm 0.66 \mathrm{~b}$ & $76.31 \pm 6.24 \mathrm{abc}$ & $16.80 \pm 1.20 \mathrm{a}$ \\
FCRF1 & $23.63 \pm 0.52 \mathrm{bc}$ & $10.22 \pm 0.10 \mathrm{a}$ & $3.97 \pm 0.29 \mathrm{~b}$ & $77.42 \pm 4.14 \mathrm{abc}$ & $15.90 \pm 0.50 \mathrm{abc}$ \\
FCRF2 & $26.60 \pm 1.98 \mathrm{~b}$ & $10.08 \pm 0.24 \mathrm{ab}$ & $4.29 \pm 0.44 \mathrm{~b}$ & $73.29 \pm 2.04 \mathrm{bc}$ & $15.40 \pm 0.60 \mathrm{abc}$ \\
FCRF3 & $31.78 \pm 0.49 \mathrm{a}$ & $9.55 \pm 0.09 \mathrm{~cd}$ & $5.26 \pm 0.01 \mathrm{a}$ & $81.99 \pm 4.61 \mathrm{a}$ & $16.40 \pm 1.60 \mathrm{ab}$ \\
\hline
\end{tabular}

Notes: The Tukey's test was used to test the effect of different treatments, and the least significant difference (LSD) was calculated to compare the differences between means in each treatment. Values are the means \pm SD of three replicates. The values followed by the different letter show statistically significant differences at $\mathrm{P}<0.05$.

\section{Discussion}

The main obstacle of the resin-coated CRF is the greater coating cost than CCF and FCRF fertilizer used in this experiment, which has prevented their extensive use in agricultural fields (Yang et al., 2012). Recently, a new CRF coated with Inorganic materials is being extended to farmers in China because of its low cost and ease of application (Hou et al., 2014). The main coating material is fly ash, a kind of industrial waster. Because of unique characteristics, the full dose of this FCRF can be provided in a single dose during the maize growing season. Because of this new FCRF's relatively low cost, its very low labor requirement, and its placement as fertilizer prills commingled with the seeds, it has the potential to be used extensively in the future production of maize and other cereal crops.

This study showed that coated fertilizers with inorganic materials amended with nitrification inhibitors increased inorganic nitrogen $\left(\mathrm{NH}_{4}^{+}-\mathrm{N}\right.$ and $\left.\mathrm{NO}_{3}^{-}-\mathrm{N}\right)$ content in soil especially at TS and PS stages of maize (Figure 2). Nitrification inhibitors reduced nitrate losses in subsurface drainage or leachate by retaining $\mathrm{N}$ in the form of $\mathrm{NH}_{4}^{+}-\mathrm{N}$ (Randall et al. 2003; Di and Cameron 2005), so inorganic nitrogen in soil can 
be lowered and the loss of ammonia by volatilization would be reduced. FCRF3, to be similar to CRF, had the higher inorganic nitrogen compared to other fertilization. It's found that the combination of coating material and nitrification inhibitors had more significant effects of keeping higher nitrogen content at later stages. Jiao et al. (2004) and Chen et al. (2005) indicated the DCD combination decreased the soil activity of urease that restrained the oxidation of urea hydrolysis, which was similar to our results. Moreover, it's helpful in that SPRP or the fly ash as coated material had controlled release effect at some degree (Hou et al. 2012; Qiu et al. 2011).

Fertilization increased SPAD index in comparison to $\mathrm{CK}$, and coated fertilizers with inorganic material amended with nitrification inhibitor increased more (Table 1). SPAD index can be used to monitor leaf $\mathrm{N}$ status, and guide fertilizer-N timing on rice, cotton, oil seed rapes (Peng et al. 2002; Zhu et al. 2006; Wood et al. 1992). That indicated the combination of coated material and physiological inhibitor can improve nutrient release effectively. What's more, FCRF2 and FCRF3 also increased $\mathrm{Pn}$ and $\mathrm{Tr}$ in leaves of maize at later stages, compared to CCF or FCRF1 (Figure 3). A similar observation was made by Haghighi et al. (2010), on corn from effects of biological fertilizer. The results also similar with Lone and Khan (2007), which showed that fertilizer treatment accounts for $40-60 \%$ increases in crop yields with the main mechanisms driven by nutrition involving plant photosynthesis, respiration and physical synthesis.

Furthermore, coated fertilizers with inorganic material amended with nitrification inhibitor increased chlorophyll fluorescence parameters at different degree (Table 2). Chlorophyll fluorescence parameters are sensitive, convenient, and non-intrusive indicators in studying photosynthetic regulation and responses to the environment of plants (Schreiber et al. 1995), and larger values of Fv/Fm indicate the higher energy capture efficiency of PS II reaction center (Xu et al. 2002); the higher level of ФPS II indicates the strong electron transport ability of the photosynthetic apparatus and the larger proportion of absorbed light energy to be used for photochemical reaction (Genty et al. 1989); the $\mathrm{qP}$ is an indicator of the open proportion of PS II reaction center (Maxwell and Johnson 2000). The well situation above also indicated the nice effect on maize growth existed at various aspects. Moreover, fertilization can increased chlorophyll fluorescence parameters compared to $\mathrm{CK}$, which was in agreement with findings of Zhao et al. (2011).

The results of this study showed that, almost all kinds of agronomic characters of maize were in a trend of FCRF $3>$ FCRF $2>$ FCRF $1>$ CRF $>$ CCF $>$ CK $\quad$ (Table 3 and Table 4). Different fertilizers or fertilization methods have different effects and mechanisms on crop growth (Elkoca et al. 2008; Samiullah et al. 1996). Application of DCD is a nitrification inhibitor and the promoting effect on growth of crop has been reported (Arshad et al. 1999; Reeves and Touchton 1989). Moreover, fertilization can improve crude fat, protein, soluble sugar, and decrease $\mathrm{NO}_{3}^{-}-\mathrm{N}$ content in different degree (Table 5), which was similar to the agronomic characters (Table 5). Fertilization increased nitrate content in crops compared with control, as found by various researchers, who studied the $\mathrm{NO}_{3}{ }^{-}-\mathrm{N}$ content in cabbage (Turan and Sevimli 2005), Chinese cabbage and spinach (Chen et al. 2004), which were different to our results. The reason may be greengrocery is more sensitive to nitrogen and has inferior nitrogen assimilation than other crops like maize. The grain yield of maize were in trend of $\mathrm{FCRF} 3>\mathrm{CRF}>\mathrm{FCRF} 2>\mathrm{FCRF} 1>\mathrm{CCF}>\mathrm{CK}, \mathrm{CRF}$ and FCRF3 significantly increased protein compared to CCF (Table 5). That indicated the combination of coating and nitrification inhibitor can make nutrient release more reasonably for maize growth, which had similar effect compared to CRF. 


\section{Conclusions}

Inorganic materials as membrane has some obvious advantages than organic polymer. Fly ash as a membrane has obvious advantages: firstly, it reduces nutrient loss and improves maize yield; secondly, it can be used as a micronutrients fertilizer and easy to decompose after applying into soil, so it could be also beneficial to environment without extra expenses. Thirdly, it can be widely applied for all farmland and crops and needs the unrestricted production equipment and relative simple techniques. By amending physiological inhibitors, the newly developed urea had more perfect effects than CCF. In this study, FCRF3 had the best effects, being similar to organic polymer coated fertilizer (CRF), while keeping the advantages of inorganic materials.

\section{Acknowledgements}

This work was financially supported by the Chinese National Basic Research Program (2015CB150404) and the Bohai sea granary engineering saline and alkaline land use program (75030).

\section{References}

Arshad, M., Zia, M.S., Ahmed, T. 1999. Effect of nitrogen sources and dicyandiamide on wheatyield, agronomic and physiological efficiency and nitrogen utilization under rainfed ecosystem. Science Vision. 4, 54-61.

Boeckx, P., Xu, X.K. , Van, C.O. 2005. Mitigation of $\mathrm{N}_{2} \mathrm{O}$ and $\mathrm{CH}_{4}$ emission from rice and wheat cropping systems using dicyandiamide and hydroquinone. Nutrient Cycling in Agroecosystems. 72, $41-49$.
Bremner, J.M., Mulvancy, C.S.. 1982. Total-Nitrogen. In: Methods of Soil Analysis, Part 2, Chemical and Microbiological Properties, eds. R.H. Miller and D. R. Keeney, pp. 595-624. Madison, Wisconsin: SSSA.

Chen, D.H., Suter, A., Islam, R., Freney, J.R.E., Walker, C.N. 2008. Prospects of improving efficiency of feriliser nitrogen in Auatralian agriculture: A review of enhanced efficiency fertilizers. Australian Journal of Soil Research. 46, 289-301.

Chen, Z.H., Chen, L.J., Wu, Z.J. 2005. Effects of urease and nitrification inhibitors on alleviating the oxidation and leaching of soil urea's hydrolyzed product ammonium. Chinese Journal of Applied Ecology. 16, 238-242.

Cui, M., Sun, X.C., Hu, C.X., Di, H.J., Tan, Q.L., Zhao, C.S. 2011. Effective mitigation of nitrate leaching and nitrous oxide emissions in intensive vegetable production systems using a nitrification inhibitor, dicyandiamide. Journal of Soils and Sediments. 11, 722-730.

Davies, H.A., Dow, J.M. 1997. Induction of extra cellular matrix glycol proteins in Brassica petioles by wounding and in response to Xanthomonas campestris, Mol. Plant-Microbe Interactions. 10, 812-820.

Di, H.J., Cameron, K. C. 2005. Reducing environmental impacts of agriculture by using a fine particle suspension nitrification inhibitor to decrease nitrate leaching from grazed pastures. Agriculture Ecosystems \& Environment. 109, 202-212.

Di, H.J., Cameron, K.C., Sherlock, R.R. 2007. Comparison of the effectiveness of a nitrification inhibitor, dicyandiamide, in reducing nitrous oxide emissions in four different soils under different climatic and management conditions. Soil Use Management. 23,1-9. 
Di, H.J., Cameron, K.C. 2003. Mitigation of nitrous oxide emissions in spray-irrigated grazed grassland by treating the soil with dicyandiamide, a nitrification inhibitor. Soil Use and Management. 19, 284-290

El-Karmany, M. 2001. Effect of organic manure and slow-release $\mathrm{N}$-fertilizer on the productivity of wheat in sandy soil. Acta Agronomica Hungarica. 49, 379-385.

Genty, B., Briantais, J. M., Baker ,N.R. 1989. The relationship between the quantum yield of photosynthetic electron transport and quenching of chlorophyll fluorescence. Biochimica et Biophysica Acta (BBA) - General Subjects. 990, 87-92.

Haghighi, B.J., Yarmahaodi, Z., Alizadeh, O. 2010. Evaluation the effects of biological fertilizer on physiological characteristic and yield and its components of Corn (Zea mays L.) under drought stress. American Journal of Agricultural and Biological Sciences. 5, 189-193.

Hou, J., Dong, Y.J. , Fan, Z.Y. 2014. Effects of Coated Urea Amended with Biological Inhibitors on Physiological Characteristics, Yield, and Quality of Peanut. Communications in Soil Science and Plant Analysis. 45, 7, 896-911.

Hou, J., Dong, Y.J., Liu, C.S., Gai, G.S., Qiu, X.K., Wang, Q.H., Fan, Z.Y. 2012. Nutrient release characteristics of controlled release fertilizers coated with superfine phosphate rock powder and its effects on physiologic traits of Chinese cabbage. Acta Pedologica Sinica. 49,17-183.

Jarosiewicz, A., Tomaszewska, M. 2003. Controlledrelease NPK fertilizer encapsulated by polymeric membranes. Journal of Agricultural and Food Chemistry. 51,413-417.

Jiao, X.G., Liang,W. J., Chen, L.J., Jiang, Y., Wen, D. Z. 2004. Effects of urease inhibitors on soil available $\mathrm{N}$ and microbial biomass $\mathrm{N}$ and on $\mathrm{N}$ uptake of wheat. Chinese Journal of Applied Ecology. 15,1903-1906.
Jumadi, O., Hala, Y., Muis, A., Ali, A., Palennari, M., Yagi, K., Inubushi, K. 2008. Influence of chemical fertilizers and a nitrification inhibitor on greenhouse gas fluxes in a corn (Zea mays L.) field in Indonesia. Microbes and Environments. 23, 29-34.

Klliher, F.M., Clough, T.J., Clark, H., Rys, G., Sedcole, J.R. 2008. The temperature dependence of dicyandiamide (DCD) degradation in soils: a data synthesis. Soil Biology and Biochemistry. 40, 1878-1882.

Li, X.L., Zhang, G.B., Xu, H., Cai, Z.C. , Kazuyuki, Y. 2009. Effect of timing of joint application of hydroquinone and dicyandiamide on nitrous oxide emission from irrigated lowland rice paddy field. Chemosphere. 75,1417-1422.

Lone, P.M., Khan, N.A. 2007. The effects of rate and timing of $\mathrm{N}$ fertilizer on growth, photosynthesis, $\mathrm{N}$ accumulation and yield of mustard (Brassica juncea) subjected to defoliation. Environmental and Experimental Botany. 60,318-323.

Maxwell, K., Johnson ,G.N. 2000. Chlorophyll fluorescence-a practical guide. Journal of Experimental Botany. 51, 659-668.

McGuinn, A.F. 1924. The action of dicyandiamide and guanyl urea sulfate on plant growth. Soil Science. 17, 487-500.

Milošević, T., Milošević, N. 2015. Apple fruit quality, yield and leaf macronutrients content as affected by fertilizer treatment. J. Soil Sci. Plant Nutr. 15 (1):76-83.

Nada, W.M. 2015. Stability and maturity of maize stalks compost as affected by aeration rate, $\mathrm{C} / \mathrm{N}$ ratio and moisture content. J. Soil Sci. Plant Nutr. 15(3):751-764.

Peng, S. B., Huang, J.L., Zhong, X.H., Yang, J. C., Wang, G.H., Zou, Y.B., Zhang, F.S., Zhu, Q. S. 2002. Research strategy in improving fertilizer nitrogen use efficiency of irrigated rice in China. Scientia Agricultura Sinica. 35,1095-1103. 
Qiu, X.K., Dong, Y.J., Hu, G.Q., Wang ,Y. H. 2011. Effects of homemade coated controlled release fertilizers on physiological characteristics, yield and quality of Chinese cabbage. Acta Pedologica Sinica. 48, 375-382.

Randall, G.W., Vetsch, J.A., Huffman, J.R. 2003. Nitrate losses in subsurface drainage from a cornsoybean rotation as affected by time of nitrogen application and use of nitrapyrin. Journal of Environmental Quality. 32, 1764-1772.

Rashda, A., Khan, M.N.1988. Modified butyrometric method for rapid determination of fat in seeds. Journal of the American Oil Chemists' Society. 12,1951-1952.

Reeves, D.W., Touchton, J.T. 1989. Effect of dicyandiamide on growth and nutrient uptake of cotton. Communications in Soil Science and Plant Analysis. 20, 2091-2103.

Samiullah, M., Ansari , S.A., Afridi , M.M.R.K. 1996. Leaf NRA and its relationship with grain and protein yield of triticale as affected by progressive application of nitrogen and phosphorus fertilizer levels. Journal of Plant Nutrition. 19,785-794.

Sartain, J.B., Hall, J.W.L., Littell, R.C. 2003. New tools for the analysis and characterization of slowrelease fertilizers. Environmental Impact of Fertilizer on Soil and Water. 872,180-195.

Schreiber, U., Bilger, W., Neubauer, C. 1995. Chlorophyll Florescence as a Nonintrusive Indicator for Rapid Assessment of In Vivo Photosynthesis, Ecophysiology of Photosynthesis, Schulze, E.D., and Caldwell, M.M.,Eds., Berlin: Springer Verlag, 49-70.
Singh, S.N., Verma, A. 2007. Environmental review: the potential of nitrification inhibitors to manage the pollution effect of nitrogen fertilizers in agricultural and other soils: a review. Environmental Practice. 9, 266-279.

Soil Science Society of China, 1999. Analyzing methods in soil and agro-chemistry. Beijing: Chinese Agricultural Science and Technology Press House.

Turan, M. , Sevimli, F. 2005. Influence of different nitrogen sources and levels on ion content of cabbage (Brassica oleracea var. capitata). New Zealand Journal of Crop and Horticultural Science. 33, 241-249.

Williams, S. 1984. Official methods of analysis of AOAC, 14th ed, pp. 830-886.

Yang,Y.C., Zhang, M., Li, Y.C., Fan, X.H., Geng,Y.Q. 2012. Improving the Quality of Polymer-Coated Urea with Recycled Plastic, Proper Additives, and Large Tablets. J. Agric. Food Chem. 60, 11229-11237.

Zaman, M., Blennerhassett, J.D. 2010. Effects of the different rates of urease and nitrification inhibitors on gaseous emissions of ammonia and nitrous oxide, nitrate leaching and pasture production from urine patches in an intensive grazed pasture system. Agriculture Ecosysterm and Environment. 136. 236-246. 